\title{
Morphological and Genetical Study on Rhizoctonia Sheath Disease Complex of Rice in Bangladesh
}

\author{
Mohammod Hossain ${ }^{1, *}$, Surapareddy Sreenivasaprasad ${ }^{2}$, Muthu Meena $^{3}$, Nitya Ranjan Sharma ${ }^{1}$ \\ ${ }^{1}$ Plant Pathology Division, Bangladesh Rice Research Institute (BRRI), Gazipur, Bangladesh \\ ${ }^{2}$ School of Life Sciences, University of Bedfordshire, Bedfordshire, UK \\ ${ }^{3}$ Warwick Crop Centre, University of Warwick, Warwick, UK
}

Copyright $\bigcirc 2017$ by authors, all rights reserved. Authors agree that this article remains permanently open access under the terms of the Creative Commons Attribution License 4.0 International License

\begin{abstract}
Morphological and molecular based experiments were conducted to identify the presence of Rhizoctonia solani, $R$. oryzae and $R$. oryzae-sativae which were the causal agents of sheath blight and sheath blight-like symptoms associated with sheath disease complex of rice. Disease survey was conducted at Bogra, Comilla, Gazipur and Rajshahi Districts in Bangladesh. The data collected revealed that sheath blight was the most important disease (19.8\%) followed by aggregated sheath spot $(2.4 \%)$, and sheath spot (2.3\%). Three pathogens of the disease complex were identified morphologically by their spot size, general appearance of spot, number of spot, position in plant, sclerotium visibility and sclerotial size on infected plant. Those three species of Rhizoctonia of rice sheath disease complex were confirmed by diagnostic-PCR with their corresponding reference isolates by using specific primers GMRS-3, GMRO-3, GMROS-2 to Rhizoctonia solani, $R$. oryzae and $R$. oryzae-sativae, respectively. Molecular approaches might overcome the limitations of morphological characterization particularly when huge samples were needed to distinguish.
\end{abstract}

Keywords Rice, Rhizoctonia Spp., Disease Complex, Diagnostic-PCR

\section{Introduction}

Most researches have been done on sheath blight disease of rice caused by Rhizoctonia solani which is one of the most important fungal diseases in the world [1]. A huge yield loss of about $50 \%$ due to this pathogen was reported when susceptible cultivars were planted $[2,3]$. But three different pathogens involved producing sheath blight complex $[4,5]$. The complexity made by 3 pathogens are Rhizoctonia solani, Rhizoctonia oryzae-sativae and Rhizoctonia oryzae causing sheath blight, aggregate sheath spot and sheath spot symptoms, respectively [6,7]. Little work has been done on aggregated sheath spot and sheath spot in Bangladesh. Morphological and Genetical Variability in Rhizoctonia solani isolates was studied by Moni et al. [20]. Some other researchers conducted studies on sheath blight disease complex in similar conditions [22, $24,25]$.

Sheath blight pathogen, $R$. solani is particularly important on food crops, where a wide range of crops may be attacked within the mixed farming systems of small-scale farmers. This fungus may survive for very long periods in soil-borne debris and on alternative hosts in rice-based cropping systems, where a range of susceptible hosts are grown adjacent or sequential to the rice crop. The other two pathogens of the disease complex, $R$. oryzae and $R$. oeyzae-sativae, while not considered being important worldwide as $R$. solani, have also been reported on rice in regions where sheath blight is important $[4,8]$. These two diseases produce almost similar symptoms like sheath blight. As a result, it becomes very difficult to distinguish the diseases especially at early stages of disease development [9]. So it becomes difficult to control the disease at early stages of plant infection.

Rice resistance to these diseases is limited and resistance screening in multi-location trials has been restricted by the inability to clear identification and assessment of these diseases. Although disease management strategies using an integrated approach are required, these are hindered by the current lack of knowledge of pathogen variability and lack of availability of methods to detect and diagnose the pathogens. The availability of an accurate and rapid diagnostic method of these pathogens is central to the implementation of appropriate integrated management strategies $[10,11]$.

The conventional diagnostic methods of pathogens are multi-stage, time consuming and labor-intensive [12]. Biotechnology is able to discriminate reliably, among closely related organisms within a population [13]. Molecular approaches may overcome the limitations of morphological characterization $[12,14,15]$.

Keeping this in view, the present investigations were 
undertaken to investigate the diversity of populations of $R$. solani, $R$. oryzae and $R$. oryzae-sativae within a field population in order to obtain a clearer picture of the relationships of such population types.

\section{Materials and Methods}

\subsection{Disease Survey and Sample Collection}

Survey was conducted during Aus (pre-wet season) Transplanting Aman (wet season) and Boro (winter season). Four districts of Bangladesh where the disease severity was high were selected. These were Bogra, Comilla, Gazipur and Rajshahi. Two Upazilas were selected in each District. Each Upazila was consisted of two Union Parishads. There were three blocks in each Union Parisad. Six fields were selected in each Block. In total, 72 rice fields in each District were surveyed for sample collection following the protocol of Savary et al. [16]. The survey sheet was designed on the basis of Zigzag sampling pattern of survey (Fig. 1).

Diseaseinfected plant parts of three species of Rhizoctonia were collected based on their symptoms (Fig. 2).

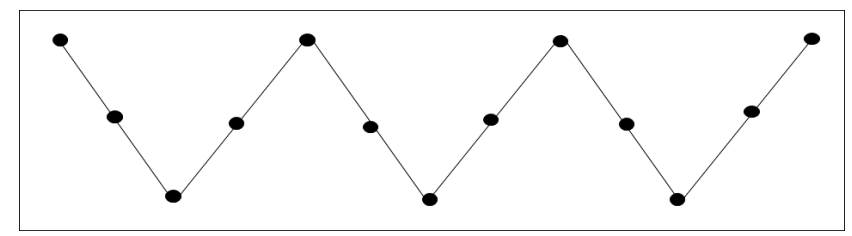

Figure 1. A Zigzag sampling pattern used in blast disease survey. Black dot indicates sampling position of the plant and black line indicates 50-step distance between two plants.

A

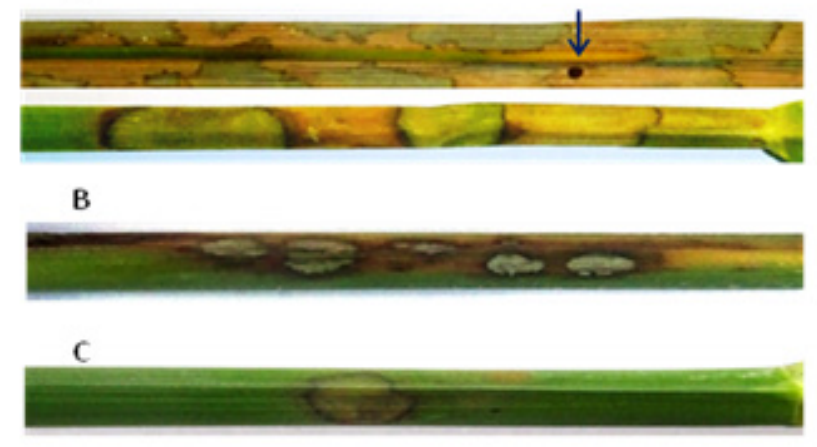

Figure 2. The symptoms produced by Rhizoctonia spp. fungi: A. Sheath Blight (Rhizoctonia solani); arrow indicates matured brown sclerotium on leaf; B. Aggregate Sheath Spot (Rhizoctonia oryzae-sativae) and C. Sheath Spot (Rhizoctonia oryzae).

\subsection{Isolation and Purification of Pathogens from Infected Plant Parts}

The pathogens associated with the disease symptoms were isolated following tissue plating method. Small pieces of infected rice stem were surface-sterilized by $1 \%$ Clorox, washed by running tap water and placed on PDA (potato dextrose agar; taken $200 \mathrm{~g}$ potato, $20 \mathrm{~g}$ dextrose and $20 \mathrm{~g}$ agar powder for 1 liter volume) media in a petri dish and kept under alternate dark and NUV light $(12 \mathrm{hr} / 12 \mathrm{hr})$ for 2-3 days to allow growing of mycelia. Single mycelial tip (hyphal tip) of the pathogen well separated from others was taken carefully with a sterile needle by using a low power stereomicroscope in a safety cabinet and transferred onto PDA media and incubated at $28^{\circ} \mathrm{C}$ in a controlled incubator for several more days. In this way, pathogens of three species of Rhizoctonia from different locations were purified.

\subsection{Morphological Identification of Three Species of Rhizoctonia}

Isolates were identified on the basis of mature colonies on PDA in petridishes and those were confirmed as the isolates of Rhizoctonia spp. [17] were retain in culture. Other identifying characteristics viz. spot size, general appearance ofspot, number of spot, position in plant, sclerotium visibility and sclerotial size were observed on infected plant.

\subsection{Diagnostic PCR for Identification of Three Species of Rhizoctonia}

\subsubsection{Preparation of Mycelia}

A small piece of purified mycelia was transferred into a flask containing liquid potato dextrose medium and grown for 5 days under room condition on a shaker. The mycelia were harvested on sterile muslin cloth, washed by sterile RO-water, squeezed to remove water and then mycelia ball was taken in sterile universal tube and then stored at $-20^{\circ} \mathrm{C}$. The frozen mycelia were freeze dried for $72 \mathrm{hrs}$ to remove water from the mycelia.

\subsubsection{DNA Preparation}

Mycelia from fungi were extracted by filtering through Whatman No. 1 filter paper and after freeze drying mycelia were kept in freezer. Liquid nitrogen was used to grind freeze dried mycelia. Total genomic DNA was harvested from mycelia of tested isolates following the extraction protocol of Lodhi et al. [18]. 
Table 1. List of isolates used in diagnostic PCR for identifying Rhizoctonia spp.

\begin{tabular}{|c|c|c|c|c|c|c|c|}
\hline SI. & Isolate & SI. & Isolate & SI. & Isolate & SI. & Isolate \\
\hline 1 & ASS (ROS) & 11 & $\mathrm{ShS}$ (RO) & 21 & $\mathrm{ShB}(\mathrm{RS})$ & 31 & $\mathrm{ShB}(\mathrm{RS})$ \\
\hline 2 & $\mathrm{ShB}(\mathrm{RS})$ & 12 & ShB (RS) & 22 & ShB (RS) & 32 & ASS (ROS) \\
\hline 3 & ASS (ROS) & 13 & ShB (RS) & 23 & ShB (RS) & 33 & ASS (ROS) \\
\hline 4 & $\mathrm{ShB}(\mathrm{RS})$ & 14 & $\mathrm{ShB}$ (RS) & 24 & $\mathrm{ShB}$ (RS) & 34 & ASS (ROS) \\
\hline 5 & ShB (RS) & 15 & ShB (RS) & 25 & ShB (RS) & \multirow{2}{*}{35} & \multirow{2}{*}{$\begin{array}{c}\text { Reference RO (ShS) } \\
\text { (EMBL accession AJ000195) }\end{array}$} \\
\hline 6 & $\mathrm{ShB}(\mathrm{RS})$ & 16 & ShB (RS) & 26 & $\mathrm{ShB}(\mathrm{RS})$ & & \\
\hline 7 & ShB (RS) & 17 & $\mathrm{ShB}$ (RS) & 27 & $\mathrm{ShB}(\mathrm{RS})$ & \multirow{2}{*}{36} & \multirow{2}{*}{$\begin{array}{c}\text { Reference ROS (ASS) } \\
\text { (EMBL accession AJ000193) }\end{array}$} \\
\hline 8 & $\mathrm{ShB}(\mathrm{RS})$ & 18 & $\mathrm{ShB}(\mathrm{RS})$ & 28 & $\mathrm{ShB}(\mathrm{RS})$ & & \\
\hline 9 & ShB (RS) & 19 & ShB (RS) & 29 & ShB (RS) & \multirow{2}{*}{37} & \multirow{2}{*}{$\begin{array}{c}\text { Reference RS (ShB) } \\
\text { (EMBL accession AJ000197) }\end{array}$} \\
\hline 10 & ShB (RS) & 20 & $\mathrm{ShB}(\mathrm{RS})$ & 30 & $\mathrm{ShB}(\mathrm{RS})$ & & \\
\hline
\end{tabular}

$\mathrm{ASS}=$ aggregate sheath spot, $\mathrm{ROS}=R$. oryzae-sativae, $\mathrm{ShB}=$ sheath blight, $\mathrm{RS}=R$. solani, $\mathrm{ShS}=$ sheath spot, $\mathrm{RO}=R$. Oryzae

Table 2. List of primers used in diagnostic PCR for identifying Rhizoctonia spp.

\begin{tabular}{|c|c|c|c|}
\hline Primer & Sequence $\left(5^{\prime}-3^{\prime}\right)$ & $\mathrm{R} / \mathrm{F}^{*}$ & Remarks \\
\hline GMROS-2 & CGG CTC ATC CTT GAA AAA TCC & $\mathrm{R}$ & Specific for $R$. oryzae-sativae \\
\hline GMRS-3 & AGT GGA ACC AAG CAT AAC ACT & $\mathrm{R}$ & Specific for $R$. solani \\
\hline ITS1 & TCC GTA GGT GAA CCT GCG G & $\mathrm{F}$ & White et al., 1990; F for GMROS-2 and GMRS-3 \\
\hline GMRO-3 & TAC GCC TTG AAG TCC CTG TAG & $\mathrm{F}$ & Specific for $R$. oryzae \\
\hline R635 & GGT CCG TGT TTC AAG ACG G & $\mathrm{R}$ & Liu et al., $1991 ;$ R for GMRO-3 \\
\hline
\end{tabular}

*Direction as $\mathrm{R}$ for Reverse and $\mathrm{F}$ for Forward

\subsubsection{PCR Analysis}

Five $R$. oryzae-sativae, one $R$. oryzae and twenty-eight $R$. solani isolates with their corresponding reference isolates [5] and one negative control were used in this experiment (Table 1). The volume of PCR reaction was $25 \mu 1$ containing DNA template $5 \mu \mathrm{l}(@ 1 \mathrm{ng} / \mu \mathrm{l})$, Ready-mix Red Taq $12.5 \mu \mathrm{l}$, primer (forward) $2.5 \mu \mathrm{l}$, primer (reverse) $2.5 \mu \mathrm{l}$ and SD water $2.5 \mu$ l. Species specific primers, GMROS-2 (Specific for R. oryzae-sativae), GMRS-3 (Specific for $R$. solani), GMRO-3 (Specific for $R$. oryzae) were used separately in each PCR reaction (Table 2). The PCR conditions were: $94^{\circ} \mathrm{C}$ for $1 \mathrm{~min}$ followed by $60^{\circ} \mathrm{C}$ (for primer GMRO and GMROS) or $52^{\circ} \mathrm{C}$ (for primer GMRS-3) for $1 \mathrm{~min}$; 40 cycles having $72^{\circ} \mathrm{C}$ for $30 \mathrm{sec}, 94^{\circ} \mathrm{C}$ for $30 \mathrm{sec}$ and $60^{\circ} \mathrm{C}$ or $52^{\circ} \mathrm{C}$ for $30 \mathrm{sec}$ for each cycle. Finally, it was run at $72^{\circ} \mathrm{C}$ for $5 \mathrm{~min}$. In gel electrophoresis, $2.5 \%$ agarose gel for $R$. solani and $1.5 \%$ agarose gel both for $R$. oryzae-sativae and $R$. oryzae were used. Gel was run for $1 \mathrm{hr}$ at $100 \mathrm{~V}$. Ethidium bromide @ 2.5 $\mu \mathrm{l} / 100 \mu \mathrm{l}$ of $0.5 \mathrm{X}$ TBE buffer was used both in tank and gel buffer for staining.

\section{Result and Discussion}

Disease survey: Occurrence and severity of sheath blight, sheath spot and aggregated sheath spot were surveyed in Rajshahi, Gazipur, Comilla and Bogra during Aus (pre-wet season) rice, transplanted Aman (wet season) rice and Boro (winter) rice. Disease survey results were presented in Figure 3, 4 and 5. All the three pathogens of rice sheath disease complex were recorded in surveyed locations. Sheath blight (19.8\%) was recorded as the most prevalent disease in all the locations and seasons followed by aggregated sheath spot (2.4\%) and sheath spot (2.3\%) (Fig. 3). Maximum sheath blight was recorded at Rajshahi (41\%) while minimum (18\%) at Bogra. About $82 \%$ samples were collected from Comilla as aggregated sheath spot which was the maximum. Sheath spot was also maximum (83.7\%) at Comilla district. But incidence of aggregated sheath spot and sheath spot were the minimum at other three (Bogra, Gazipur and Rajshahi) districts (Fig. 4). Among the seasons, Aus crop (pre-wet season; 25.5\%) was the most favourable for sheath blight disease followed by T. Aman crop (wet season; 16.3\%) and Boro crop (winter season; 12.1\%) (Fig. 5).

Wide scale adoption of highly susceptible cultivars and intensification with mono crop rice cultivation appeared to be the major causes of high sheath blight incidence. Use of high dose of nitrogenous fertilizer and closer spacing might be the other courses for high incidence. Intensive disease survey indicated $R$. solani (sheath blight) as the dominant pathogen and importantly identified wide occurrence of $R$. oryzae-sativae either singly or along with $R$. solani in rice production system in Bangladesh. Sheath blight disease requires high humidity and high temperature in the crop canopy to develop vertically and horizontally. Boro is dry season maintaining lower humidity and temperature in the 
crop canopy in the field compared to T. Aman and T. Aus seasons which might be the reason having more disease in wet season than dry season. Similar observations were made by Moni et al. [20], Rashad et al. [21], Akter et al. [22], Gue et al. [23], Inagaki et al. [4] and Shajahan [24].More disease in wet season than dry season was also recorded by Sharma et al. [25] and Sreenivasaprasad [26]. The present study was in accordance with their findings.

The lowest incidence of ShS and ASS were associated with highest severity of ShB in Rajshahi and the highest incidence of $\mathrm{ShS}$ and ASS were associated with lowest severity of ShB in Comilla. The results indicated that ShB pathogen might have been suppressed by ShS and ASS perhaps by antagonistic interactions among them. Our findings were supported by the results of Akter et al. [27], Sharma et al. [25] and Sreenivasaprasad [26].

Differences in Sheath blight severity between fields was visible even within the same block possibly due to the differences in primary inocula and also differences in crop management practices such as irrigation water, spacing between plants and rows. The three pathogens of sheath blight, sheath spot and aggregated sheath spot are soil borne and spread locally mostly during land preparation through irrigation water and agricultural implements. Accumulation of higher number of pathogen propagules in a particular field within a block is not unlikely and that might be another reason for differences in disease incidence between fields. Variation in crop varieties used and cultural practices such as fertilizer use between fields might have also affected disease incidence. Sreenivasaprasad [26] and Taheri et al. [28] reported the similar results which supported the present study.

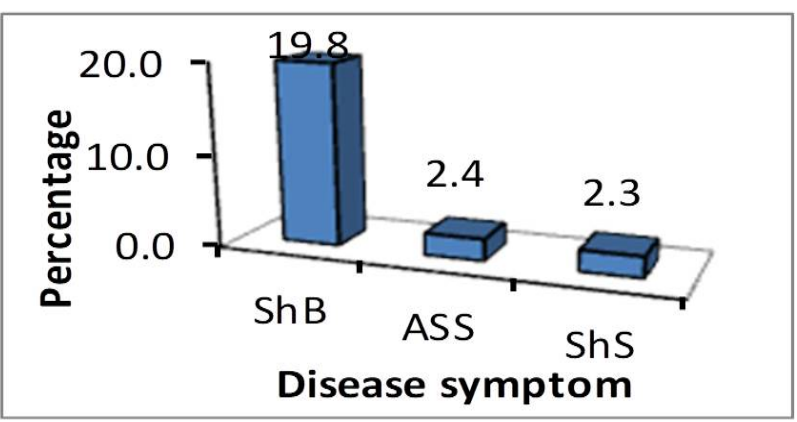

Figure 3. Mean incidence of sheath blight, aggregated sheath spot and sheath spot diseases of rice in Bangladesh

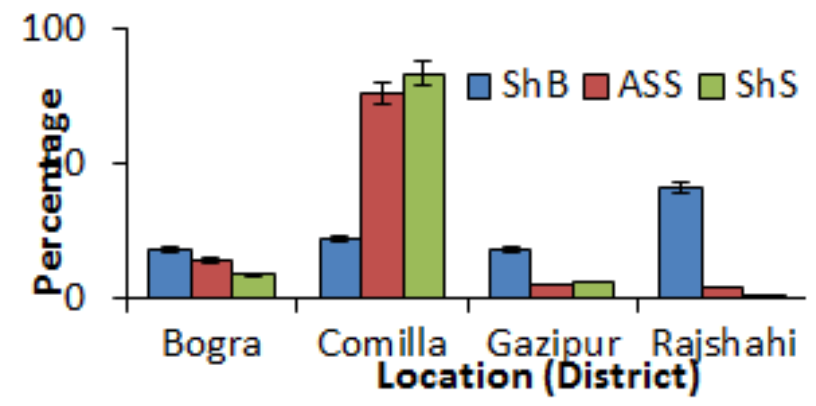

Figure 4. Presence of sheath blight, aggregated sheath spot and sheath spot diseases at Bogra, Comilla, Gazipur and Rajshahi sites

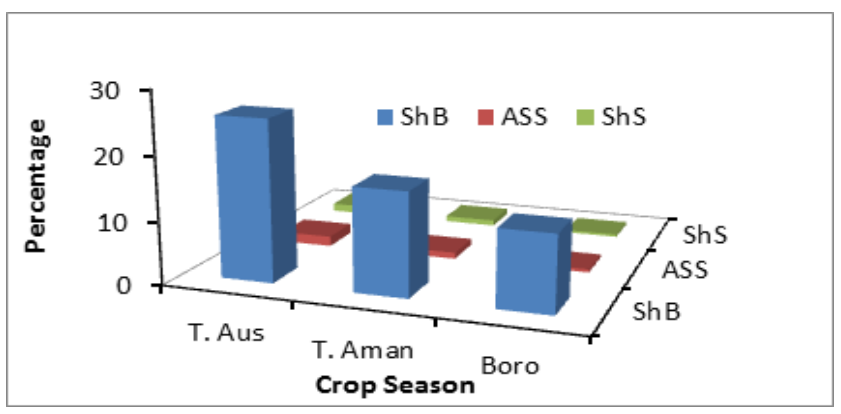

Figure 5. Seasonal occurrence of sheath blight, aggregated sheath spot and sheath spot diseases of rice

\section{Morphological Identification of Three Species of Rhizoctonia}

Disease characteristics on plant produced by Rhizoctonia spp. were presented in Table 3. Several large spots $(1-3 \mathrm{~cm})$ of sheath blight were observed on sheath and leaf of rice plant. The sclerotium size was around $2 \mathrm{~mm}$ and easily visible on the spot. Sheath spot symptom was medium in size $(0.5-1 \mathrm{~cm})$, single spot appeared on sheath only and sclerotium was not visible on spot. Several small $(0.5-1 \mathrm{~cm}$ size $)$ aggregate sheath spots were found on leaf and sheath and their sclerotia were not visible on spot. Similar results were described by Sharma et al. [25], Sreenivasaprasad [26] and Amaradasa [29]. Present study was in accordance with their findings.

\section{Diagnostic PCR for Identification of Three Species of Rhizoctonia}

All the DNA of 37 isolates of Rhizoctonia spp., of which five from $R$. oryzae-sativae (ASS), one from $R$. oryzae (ShS), 28 from $R$. solani (ShB) and three from standard reference isolates, were amplified in PCR using primers GMROS-2 (Specific for $R$. oryzae-sativae), GMRO-3 (Specific for $R$. oryzae) and GMRS-3 (Specific for $R$. solani), respectively with their corresponding standard reference isolates. The result was presented in Figure 6. The primer GMROS-2 annealed only with the DNA of $R$. oryzae-sativae and its standard reference isolate. So, only the DNA of $R$. oryzae-sativae was amplified. After gel electrophoresis and staining of gel, only sample number 1 , $3,32,33,34$ and reference isolate 36 were visualized at the same position. It indicated that those isolates were $R$. oryzae-sativae (Figure 6A). In the same way, primer GMRO-3 annealed with the DNA of sample number 11 and its reference isolate 35 . Hence only they were visualized in gel at the same position (Figure 6B) indicating that it was $R$. oryzae. Primer GMRS-3 annealed with isolate number 2, 4-10, 12-31 and their reference isolate 37. Therefore, only DNA of those isolates were amplified and visualized in gel at the same position which indicated that those isolates were R. solani (Figure 6C). For all the PCRs, negative control (without DNA template) didn't amplify indicating that the PCR reagents used in the reactions were non-infected by any foreign DNA. 
Table 3. Morphological characteristics of Rhizoctonia sheath disease complex on rice plant

\begin{tabular}{|c|c|c|c|c|c|c|}
\hline \multicolumn{6}{|c|}{ Disease characteristics on plant } & \multirow[b]{2}{*}{ Disease identification } \\
\hline Appearance of spot & $\begin{array}{c}\text { Spot size } \\
(\mathrm{cm})\end{array}$ & $\begin{array}{c}\text { Number of } \\
\text { spot }\end{array}$ & $\begin{array}{c}\text { Position in } \\
\text { plant }\end{array}$ & Sclerotia in plants & $\begin{array}{c}\text { Sclerotia } \\
\text { Size }(\mathrm{mm}) \\
\end{array}$ & \\
\hline Large & $1-3$ & Several & Sheath \& leaf & Visible & 2 & Sheath blight \\
\hline Medium & $0.5-2$ & Single & Sheath & Not visible & - & Sheath spot \\
\hline Small & $0.5-1$ & Several & Sheath \& leaf & Not visible & - & Aggregate sheath spot \\
\hline
\end{tabular}

Visual diagnose of Rhizoctonia species infected sheath diseases of rice are comparatively difficult due to the similarity of the symptoms with those caused by other disorders. The pathogens $R$. oryzae and $R$. oryzae-sativae, which produce very similar symptoms in the field, have been reported on rice in many countries from eastern and south-eastern Asia [4, 30].

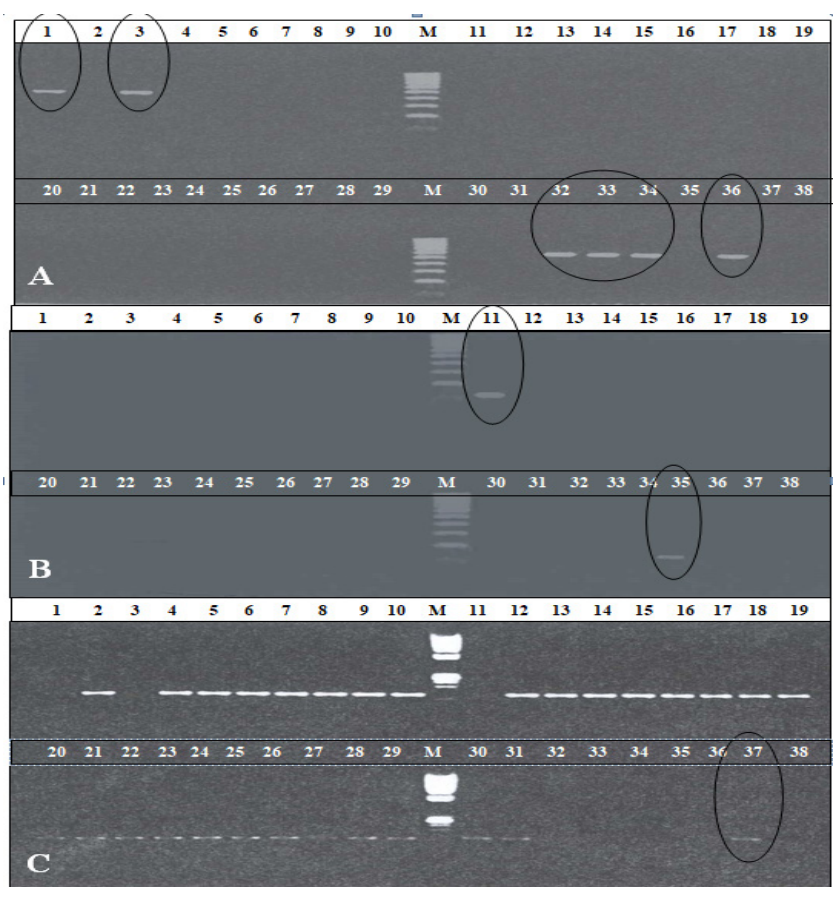

Figure 6. Diagnostic PCR for (A) R. oryzae-sativae, (B) R. oryzae and (C) R. solani using specific primer GMROS-2, GMRO-3 and GMRS-3, respectively.

In the diagnostic PCR, specific primer to Rhizoctonia spp. were used to develop a rapid PCR based diagnostic test and provided an accurate identification of the Rhizoctonia spp. on rice. Johanson et al. [5] described test on the specificity of the primers and showed that species specific primers provided the means for accurate identification of the Rhizoctonia species responsible for sheath diseases in rice. Sreenivasaprasad [26] and Matsumoto et al. [6] described PCR based analysis for the possibility of direct diagnosis of $R$. solani, R. oryzae and $R$. oryzae-sativae. The present study was also supported by them.

Utilization of molecular tool in combination with intensive disease survey confirmed the presence of those three pathogens in rice sheath disease complex in
Bangladesh. Together with morphological characters, these molecular markers revealed diversity not only between isolates from geographically different regions, but also within ones from the same or similar agro-ecological regions $[20,31]$.

\section{Conclusions}

All the three pathogens of rice sheath disease complex were recorded in surveyed locations. Irrespective of location $R$. solani $(\mathrm{ShB})$ was the major pathogen followed by $R$. oryzae satieve (ASS) and $R$. oryzae (ShS). Maximum $\mathrm{ShB}$ was recorded in Rajshahi district while maximum ASS and ShS were observed in Comilla district. Among the cropping seasons, Aus was the most favourable for sheath blight disease followed by T. Aman and Boro season. Morphologically, three pathogens of rice sheath disease complex was identified though it was multi-stage, time consuming, labor-intensive and comparatively difficult to diagnose due to the similarity of the symptoms with those caused by other disorders. But diagnostic PCR-based technology identified those pathogens rapidly and accurately which might overcome the limitations of morphological characterization.

\section{REFERENCES}

[1] Kobayashi T., Mew T. W. and Hashiba T., 1997. Relationship between incidence of rice sheath blight and primary inoculum in the Philippines: mycelia in plant debris and sclerotia. Annals of the Phytopathological Society of Japan 63: 324-327.

[2] IRRI 2017: Rice knowledge bank. International rice research institute, Philippines. Available at

'http://www.knowledgebank.irri.org/decision-tools/rice-doc tor'.

[3] Ou, S. H. 1985. Rice Diseases, 2nd edn. Commonwealth Agricultural Bureau, Slough.

[4] Inagaki K., Qingyuan G., Masao A., 2004. Overwintering of rice sclerotial disease fungi, Rhizoctonia and Sclerotium spp. in paddy fields in Japan. Plant Pathology Journal 3: 81-87.

[5] Johanson, A., Turner, H. C., McKay, G. J., and Brown, A. E. (1998). A PCR-based method to distinguish fungi of the rice sheath-blight complex, Rhizoctonia solani, $R$. oryzae and $R$. 
oryzae-sativae. FEMS Microbiological Letters, 162 (2). 289-294.

[6] Matsumoto, M., Furuya, N., Takanami, Y. and Matsuyama, N. 1997. Rapid detection of Rhizoctonia species, causal agent of rice sheath diseases, by PCR-RFLP analysis using an alkaline DNA extraction method. Mycoscience38 (4): 451-454.

[7] Sneh, B., Burpee, L. L., \& Ogoshi, A. (1991). Identification of Rhizoctonia species. St. Paul, Minnesota: American Phytopathological Society Press, pp. 133.

[8] Lanoiselet, V. M., Cother, E. J. and Ash, G. J. 2007. Aggregate sheath spot and sheath spot of rice. Crop Protec. 26: 799-808

[9] Lanoiselet, V. M., Cother,E. J., Cother, N. J., Ash, G. J. and Harper,J. D. I. 1998. Comparison of two total cellular fatty acid analysis protocols to differentiate Rhizoctonia oryzae and $R$. oryzae-sativae. Mycologia, 97(1), 77-83.

[10] Matsumoto, M. 2002. Trials of direct detection and identification of RhizoctoniasolaniAG1 and AG2 subgroups using specifically primed PCR analysis. Mycoscience43: 185-189.

[11] Zeller, K. A., Jurgenson J. A., El-Assiuty E. M. and Leslie J.F. (2000). Isozyme and amplified fragment length polymorpisms (AFLPs) from Cephalosporium maydis in Egypt. Phytoparasitica: 28, 121-130.

[12] Ball, S. F. L. and Reeves, J.C. 1991. The application of new techniques in rapid testing for seed-borne pathogens. Plant Varieties and Seeds 4: 169-176.

[13] Dobinson, K. F., Patterson, N. A., White, G. J. and Grant, S. (1998). DNA fingerprinting and vegetative compatibility analysis indicates multiple origins for Verticillium dahliae race 2 tomato isolates from Ontario. Canada. Mycil. Res.: $102,1089-1095$.

[14] Foster, L. M., Kozak, K. R., Loftus, M. G., Stevens, J. J. and Ross, I. 1993. The polymerase chain reaction and its application to filamentous fungi. Mycol. Res. 97: 769-781.

[15] Reeves, J.C. 1995. Nucleic acid techniques in testing seed-borne pathogens. In: New Diagnostics in Crop Sciences. (Eds. Skerritt, J.H. and Appels, R.), CAB International, Oxon, UK. 127-151pp.

[16] Savary S, Elazegui FA, Teng PS 1996: A survey portfolio for the characterization of rice pest constraints. IRRI Discussion Paper Series No. 18. International Rice Research Institute, P.O. Box 933, Manila, Philippines, pp. 31.

[17] Ogoshi, A. 1996. The genus Rhizoctonia. Pages 1-9 in: Rhizoctonia species: Taxonomy, Molecular Biology, Ecology, Pathology and Disease Control. B. Sneh, S. Jabaji-Hare, S. Neate, and G. Dijst, eds. Kluwer Academic Publishers, Dordrecht, the Netherlands.

[18] Lodhi, M. A., Ye, G. N., Weeden, N. F. and Reisch, B. 1994. A simple and efficient method for DNA extraction from grapevine cultivars and Vitis species. Plant Mol. Biol. Rep. 12, 6-13.

[19] White T. J., Bruns T., Lee S. Taylor J.W. (1990) Amplification and direct sequencing of fungal ribosomal RNA genes for phylogenetics. In PCR Protocols: A Guide to
Methods and Applications (Innis M.A., Gelfand, D.H., Sninsky J.J., White T.J., Eds.), pp. 315-322. Academic Press, San Diego, CA.

[20] Moni, Z. R., Ali, M. A., Alam, M. S., Rahman, M. A., Bhuiyan, M. R., Mian, M. S., Iftekharuddaula, K. M., Latif, M. A. and Khan, M. A. I. 2016. Morphological and Genetical Variability in Rhizoctonia solani Isolates. Rice Science, 23(1): 42-50

[21] Rashad, Y. M., Abdel-Fattah, G. M., Hafez, E. E. and El-Haddad, S. A. 2012.Diversity among some Egyptian isolates of Rhizoctonia solani based on anastomosis grouping, molecular identification and virulence on common bean. Afr J Microbiol Res, 6(37): 6661-6667.

[22] Akter S., Ali, M. A., Sharma, N. R., Rahman, M. M. and Mia, M. A. T. 2009. Prevalence of three Rhizoctonia species in four regions of Bangladesh and their virulence. Bangladesh Journal of Plant Patholology, Vol.25 (1\&2): 25-30.

[23] Gue, Q. Y., Kamio, A., Sen, SH. B., Sagara, Y. Arakawa, M. and Inagaki, K. 2006. Survival and subsequent dispersal of rice sclerotial disease fungi, Rhizoctonia oryzae and Rhizoctonia oryzae-sativae, in paddy fields. Plant Dis. 90: 615-622.

[24] Shajahan, A. K. M. 1991. Comparative study on sheath blight, sheath spot and aggregated sheath spot of rice caused by Rhizoctonia species. Bangladesh J. Plant. Path. 7 (1 \& 2): 25-31.

[25] Sharma, N. R., S. Akter and M. M. Rahman. 2004. Survey on Rice (Oryza sativa L.) Sheath Blight Disease Complex in Gazipur District of Bangladesh. The Agriculturists. 2 (2):101-107.

[26] Sreenivasaprasad, S. 2004. Rice sheath blight complex caused by Rhizoctonia species: Pathogen epidemiology and management strategies. Final technical report of project ID: R 7778 (ZA 0406). University of Warwick, UK, pp. 101.

[27] Akter S., Mia, S., Kabir. M. S., Latif. M. A. and Mia. M. A. T. 2005. Avirulent Rhizoctonia oryzae controlling sheath blight of rice under field condition. Bangladesh J. Plant Pathol. 21(1\&2): 89-91.

[28] Taheri, P., Gnanamanickam, S. and Hofte, M. 2007. Characterization, genetic structure, and pathogenicity of Rhizoctonia spp. associated with rice sheath diseases in India. Phytopathology 97: 373-383

[29] Amaradasa, B. S. 2011. Accurate identification and grouping of Rhizoctonia isolates infecting turfgrasses in MD and VA and their sensitivity to selected fungicides in vitro. A PhD Dissertation submitted to the faculty of the Virginia Polytechnic Institute and State University in Plant Pathology, Physiology, and Weed Science. Blacksburg, Virginia, pp 144.

[30] Aye, S. S. and Matsumoto, M. 2011. Genetic diversity of the causal agents of rice sheath diseases in Myanmar and the grouping of Rhizoctonia solani from some rice-growing countries. Bull. Inst. Trop. Agr., Kyushu Univ. 34: 77-91.

[31] Banerjee, S., Datta, S., Mondal, A. and Bhattacharya, S. 2012. Characterization of molecular variability in Rhizoctonia solani isolate from different agro-ecological zone by random amplified polymorphic DNA (RAPD) markers. Afr J Biotechnol, 11(40): 9543-9548. 